\title{
Asthma diagnosis and treatment - 1019. Churg Strauss Syndrome - missed diagnosis and consequences
}

\author{
Mahomed Cassim Kamdar \\ From 2nd WAO International Scientific Conference (WISC 2012) \\ Hyderabad, India. 6-9 December 2012
}

\section{Background}

To have a high index of suspicion for diagnosing Churg Strauss Syndrome in patients presenting with asthma symptoms, pulmonary infiltrates and various systemic manifestations of the disease.

\section{Methods}

Case notes with investigations was retrieved from various specialists attending to the index patient with undiagnosed pulmonary symptoms and pulmonary infiltrates withsystemic disease,especially chronic abdominal symptoms over a two year period. During the patient's last admission she again presented with intractable abdominal pain, pyrexia, systemic hypertension (BP 170/140), loss of weight, emaciated $(24 \mathrm{Kg})$, purpuric eczematous rash on the upper limb,unable to walk with marked weakness (polyneuropathy) and was being prepared for laparoscopic cholecystectomy by the surgeons for suspected cholecystitis.

\section{Results}

Review of data and clinical features revealed a classical case of Churg Strauss Syndrome, highlighting the phasic nature of the disease.Beginning with the prodromal allergic phase progressing to the eosinophilic phase, vasculitic phase and post-vasculitic phase.

\section{Conclusions}

A classic case of undiagnosed Churg Strauss Syndrome over a 2-year period highlighting the sequential $\mathrm{x}$-ray chest, CT, histological features (endoscopy and abdominal laparoscopy) and the systemic manifestation of the disease

Medicine and Pulmonology, Nelson Mandela School of Medicine University of KwaZulu Natal/ RK Khan Hospital, South Africa with a brief review of the topic. Suitable for 20 or $30 \mathrm{~min}$ utes oral presentation.

Published: 23 April 2013

doi:10.1186/1939-4551-6-S1-P19

Cite this article as: Kamdar: Asthma diagnosis and treatment - 1019.

Churg Strauss Syndrome - missed diagnosis and consequences. World

Allergy Organization Journal 2013 6(Suppl 1):P19.
Submit your next manuscript to BioMed Central and take full advantage of:

- Convenient online submission

- Thorough peer review

- No space constraints or color figure charges

- Immediate publication on acceptance

- Inclusion in PubMed, CAS, Scopus and Google Scholar

- Research which is freely available for redistribution

\section{() Biomed Central}

C Biomed Central

(c) 2013 Kamdar; licensee BioMed Central Ltd. This is an Open Access article distributed under the terms of the Creative Commons Attribution License (http://creativecommons.org/licenses/by/2.0), which permits unrestricted use, distribution, and reproduction in any medium, provided the original work is properly cited. 